\title{
Psalm 74: myth as the source of hope in times of devastation
}

G Baumann $^{1}$

(Philipps-Universität, Marburg)

\section{ABSTRACT}

Psalm 74: Myth as the source of hope in times of devastation

The reference to mythical traditions in Psalm 74 is not just an allusion to a common set of motifs. It is an essential strategy to gain hope in desperate times, when the country is completely destroyed. The article shows this mainly by working on the structure and the metaphors of the psalm. The authors of Psalm 74 created hope in a hopeless situation by referring to a dimension beyond the visible sphere. The deeds of YHWH/Elohim in the mythical traditions cannot be reached by the enemies: the God-established orders of time and space cannot be destroyed by their violence.

\section{INTRODUCTION}

When speaking about mythical texts or traditions in the Bible, one occasionally faces critique that is based on the assumption that 'myth' cannot claim the same dignity or truth as 'history' or Heilsgeschichte [cf e.g. Lelièvre (1976) or Oswalt (1977)]. Psalm 74 is one of the texts that serve as an example for the ruling of Heilsgeschichte over 'mythical tradition'. Keeping this controversy in mind, my approach to Psalm 74 starts from a synchronic and theological perspective, enquiring as to the results of reading the psalm in its literary and historical context.

Psalm 74 confronts its readers with a violent god who is angry with the Israelite people and therefore lets their enemies destroy the land and the temple. There is a complete lack of any visible order. The situation from which Psalm 74 speaks is that of a desperate search for a source of hope. Where did the authors find this hope, and how did they express it in the text?

After this introduction, part 2 presents a structural analysis of Psalm 74 and its three parts (I-III). It gives special reference to terms of space and time and to how images of the divine are used. In part 3 , a closer look at these images will illustrate the field of traditional

1 Dr Baumann is a research associate of the Department of Old Testament Studies at the University of Pretoria. 
speech and thinking to which they belong. This is reflected in the concluding part 4, with respect to the question of 'myth' and 'history'.

\section{STRUCTURAL ANALYSIS OF PSALM 74}

\subsection{The division into three parts}

Psalm 74 can be divided into three parts ${ }^{2}$. By doing this, I leave aside the superscription (Ps 74,1a $\alpha$ ) that identifies the psalm as belonging to the Asaph-psalms (50, 73-82). Like most of the other Asaph-psalms, Psalm 74 is a communal lament, generally recognised as an exilic psalm (Zenger 2000:356-360) ${ }^{3}$.

There are considerable arguments for a division of the psalm into three parts: verses 1a $\beta-11$ (part I), verses 12-18 (part II) and verses 19-23 (part III) ${ }^{4}$. Each part addresses God in the first hemistich (Elohim in v. 1 b and 12 and YHWH in v. 18). Part I (vv. $1 \mathrm{a} \beta-11)$ is framed by the mentioning of two words, namely $\mathrm{hml}$ 'why' (v. 1a $\beta, 11 \mathrm{a})$ and $\mathrm{j} \times \mathrm{n}$ 'forever' (1a $\beta .10 \mathrm{~b})$. This already points to the seemingly hopeless situation of the Israelite people. There is a minor break in the middle of this first part of the psalm, brought about by $t$ [ 'now', as the first word of verse 6 . The beginning of part II (v. 12-17) is marked by the adversative $W$ and another appeal to Elohim, who is depicted as king and creator of the world order. The personal pronoun hta 'you' emphasises the address in the second person singular, and the last of the personal pronouns is found in verse 17, which also forms the last verse of this second part

2 For the discussion on the structure of the psalm up to the early 1970's, cf Van der Ploeg (1974:204-210).

3 Cf also Donner (1973:41-50) who tries again to raise the discussion of a Maccabean origin of the psalm, or Weber (2000:523-528, 530f), who opts for the second half of the eighth century BCE.

4 Human (1993a:152) proposes a different structure for the psalm, in which verses $1 \mathrm{a} \beta .11$ are divided into three parts. These first three parts are, however, still closely connected by the laments and the imperative forms in vv 1-3 and 9-11 (Human 1993a:160, 165; 1993b:206, 208), so that it seems possible to look at them as one part of the psalm.

$5 \quad$ I do not think, as Weber does (2003:24.26), that one should consider this break a major one, which leads to a four-part-structure of Psalm 74. Part I of the psalm is held together by the mentioned frame, and vv 5 and 6 are closely related by both describing one scene of destruction of the sanctuary. 
of the psalm. Part III consists of vv 18-23. It begins with the imperative $r k z$, now addressing YHWH instead of Elohim, which is repeated in verse $22 \mathrm{~b}$. This passage is mainly framed by the mentioning of the respective enemies of either YHWH or Israel in verse 18a.b and 23.a.b. It appears to me that the $\mu y l b n$, the 'foolish' ( $18 \mathrm{~b}$ and $22 \mathrm{~b}$ ), also belong to the group of the enemies, which by this means has been extended throughout the psalm.

We will now take a closer look at each of the three parts and their structure.

\subsubsection{Part I: verse 1a $\beta-11$}

The outer frame of the psalm's first part is formed by $\mathrm{hml}$ 'why' (v. $1 \mathrm{a} \beta, 11 \mathrm{a})$ and $\mathrm{j} \times \mathrm{n}$ ' 'forever' $(1 \mathrm{a} \beta, 10 \mathrm{~b})$. This framing already points to the hopelessness of the Israelites' situation, and is alluded to again at the end of the passage in the double question $h \mathrm{mAd}[$ or yt mAd [ 'how long' (vv. 9b, 10a). These questions also belong to the outer frame. The four words of the outer frame address the category of time.

Besides the outer frame, there is also an inner one, formed by the mentioning of the enemies ( $b$ y $1, r r x$ and $r x$ ) in verses $3 b, 4 a$ and 10a.b. In the verses in the middle of this double frame, we find expressions of totality like $\mid k$ (vv. 3b, 8b) and dj y (6a, 8a), which predominantly refer to the total destruction of the land and the temple, as well as to the overall oppression of the people. They culminate in the quotation of the enemies' speech: 'We will utterly subdue them!' These expressions of totality refer to the dimension of space. Israel/Zion is, spoken in terms of poetry, completely 'surrounded' by her enemies.

From verses $3 \mathrm{~b}$ to $8 \mathrm{~b}$, all verbs refer to the violent and destructive activities of the enemies. Except for the imperfects in vv $5 \mathrm{a}$ and $6 \mathrm{~b}$, there are only perfect verbal forms. The verses $5 \mathrm{a}$ and $6 \mathrm{~b}$ cause difficulties in understanding and interpretation ${ }^{6}$. What seems to be clear, however, is that with the help of axes and hatchets or hammers, the interior part of the temple with its fine woodwork has been destroyed as if it were merely wood and trees.

6 I agree with Emmendörffer (1998:79), who states, "Die hier dargebotene Übersetzung der Verse 5 und 6 stellt den Versuch dar, dem schlechten und nicht aufhellbaren Textbestand von $M$ [the Massoretic text] einen Sinn abzugewinnen". 
The verses 3b-10a generally consist of non-metaphorical language. The destruction of the sanctuary is described in very clear terms. This is different with the opening passage of part $\mathrm{I}$, as well as in its end. The verses 1-3 and 10-11 are addressed to Elohim. He is accused of having cast off his people (v. 1a $\beta$ ) and of being angry with them in spite of acting as their shepherd (v. 1b). This is, according to Zenger (2000:363), some kind of 'reversed use' of the metaphor of the shepherd: "Statt sich als fürsorglicher, schützender Hirte um seine Herde zu kümmern (vgl. Ps 80:2) und die Feinde, die sie bedrohen, zu vertreiben, hat JHWH seine Herde nicht nur im Stich gelassen, sondern auch den 'Rauch seines Zornes' gegen sie geschickt". Instead of giving his sheep the shelter they need, he is angry with them.

In the one-and-a-half verses that follow the psalm's headline, we find a combination of at least five theological traditions of Israel (Zenger 2000:363): Elohim has cast off his people (1aß). This is a reversal of a motif from the theology of Israel being God's chosen people. This tradition is also alluded to in verse 2, where Elohim is called to remember that he was the one who had once created or acquired ( $h n q)$ his people (Ex 15:16). God's wrath (v. 1b) is often found in prophecy, in theophany or in divine judgement. The image of the divine shepherd (v. 1b) belongs to the wider range of the metaphor of the king for Elohim/YHWH, and is mainly found in prophecy and the psalms. These motifs are followed by a reference to Zion theology (v. 2a), in combination with the deuteronomistic term of Zion as the dwelling place of YHWH/Elohim (v. 2b) or his name (Human 1993b:210). The opening of Psalm 74 therefore is a text that alludes to older Israelite traditions to a high degree.

The same goes for the end of part I, and in verses 9-11 we find other references to Old Testament traditions. The t ut a 'signs' might refer to cult or prophecy. Prophecy - or the lack thereof - is explicitly mentioned in verse 9 . This points back to the 'signs' of the enemy, which should probably be understood as military emblems now standing in the temple (v. $4 b$ ).

In verse 10, Elohim is for the first time in the psalm not addressed as cause of the damage by not interrupting the enemies' activities, but as one of those who suffers - alongside with his people - due to the damage done by the enemies. This is also indicated by positioning Elohim within the frame formed by the 
mentioning of the enemies. The enemy reviles Elohim's name j $x \mathrm{nl}-$ 'forever', the same $j \times n$ which was ascribed to Elohim's casting off of his people in verse 1 . In this rhetoric, the psalm argues that Elohim's anger against his people does not make sense, because not only are the people harmed, but Elohim's own sanctuary and dwelling place is destroyed as well. The reason for this argument is to convince Elohim that he should take action - which is metaphorically destribed in an imperative phrase in verse 11: Elohim is demanded to take his hand out of his garment ${ }^{7}$ instead of being passive and allowing the work of destruction to be continued. The hand (d $[$ ) and the right hand (Hmy) of Elohim are probably to be seen as carrying weapons like the Ugaritic or Mesopotamian weather or war gods Ba'al or Ninurta. Therefore, the divine warrior is addressed here. Like the shepherd, this also is part of the ancient Near Eastern royal ideology. This line is followed in the last word of this section, which is again an imperative: Elohim shall make an end (alk) to the destructive work of the enemies.

There are other elements in this first part of the psalm on which we will not go into further detail. These include the theology of the name of Elohim (vv. 7b, 10b) and the imperative forms that underline the lament of Israel/Zion (vv. 2a, 3a, 11b). More important in our search is the fact that the enemies' hostile or violent acts and the divine passiveness are described in present tense or in the near past (imperfects: vv. 1b, 5a, 6b, 10a, 10b, 11a), whereas the positive act of Elohim's choosing Israel is remembered in past tense (v. 2). This already points to what follows in the next part of the psalm: Elohim's positive deeds or acts are situated in the temporal dimension of the past.

\subsubsection{Part II: verses 12-17}

Although the verses 11 and 12 - and therefore between parts I and II - are separated by the adversative $w$, there are also connecting elements between both paragraphs. Verse $11 \mathrm{~b}$ begins with $\mathrm{br}$ q $\mathrm{m}$. The same noun $b r q$, 'middle', with the preposition $b$ is found in verse $12 \mathrm{~b}$. In between, the nominal sentence verse $12 \mathrm{a}$ ends with $\mu \mathrm{dqm}$, which is another segolate noun $\mu d q$ ('times of old'), beginning with q and therefore resembling br q m. Elohim is demanded to take his hand

7 In this, I follow the reading $\mid \mathrm{yx}$ which is proposed by the Qere of the Masoretic text. 
out of (br q m) his garment (v. 11b). As the king from of old ( $\mu d q m)$, he is the one who brings forth salvation to the midst of the land or earth. Ar a serves as a framing word for part II (vv. 12b, 17a). Elohim, who has been Israel's (the first person singular) king since the primordial times, is supposed to take action and stop the destruction in fulfilling this role. These expressions refer to the past, as did the positive images of God in the psalm's first part.

The structure of part II is somehow different from part I. Verse 12 (A) is an opening line and functions as some kind of a headline for verses 13-17. It has, however, also another function for the psalm as a whole: it is the central verse of psalm 74 and therefore carries even more weight. In verse 12, the role which establishes Elohim's relationship to his people is unmistakably formulated and is also demanding in direction to God: He has been Israel's king since the primordial times $(\mu d q m)^{8}$, and the core of this role is to take care for his people and save them. The term tW Wy, 'salvation', is often used in psalms, but also refers to the exodus and the salvation at the Red Sea (Ex 14:13, 15:2). What is said in verse 12? Elohim is the one who is capable to save and liberate at all times and all places. It is he who is responsible to stop the destructive acts of the enemies, if he really is the king of Israel.

The verses 13-17 are closely connected by the repetition of the personal pronoun ht a, 'you', which is used at least once in every verse and seven times in total. This use of the seven, the number of totality, can be interpreted as a counterstatement against the total destruction of the enemies in part I. The verses 13-17 form a concentric structure, and we find another two highly developed structures in its framing verses $13 \mathrm{f}$ and $16 \mathrm{f}$. To begin with the broader structure: Verse $13 \mathrm{f}(\mathrm{B})$, depicts Elohim as warrior against the chaotic beings or sea monsters, and v $16 f\left(B^{\prime}\right)$ emphasises the role of the deity as the one who establishes the everlasting cosmic order. The connecting topic of this frame is the establishing of divine order in the world. Verse 15 (C), in the centre of this frame, at first sight deals with the divine aggression against the rivers. At second sight, however, it refers or alludes to the exodus and God's saving of his people or to theophanic traditions. In texts of theophany like

8 For the mythical and historical implications of $\mu d q$, cf Koch (1991[1988]:254-259). 
Psalms 18:16, 77:17f, 89:10 or Habakuk 3:8f, YHWH intimidates the waters and other cosmic elements. More specific for the exodus is the verb [ $a b$, used for YHWH's splitting of the waters of the Red Sea in Exodus 14:16, Isaiah 63:12, Psalm 78:13 and Nehemiah 9:11. Also, the drying (v by Hif) of the waters refers to the same scene in Joshua 2:10 and 4:23. Therefore, the structure is as follows: $A-B-$ $\mathrm{C}-\mathrm{B}^{\prime}$. A (v. 12) is related to both $\mathrm{B} / \mathrm{B}^{\prime}$ and $\mathrm{C}$ : the connection between verses $12,13 \mathrm{f}$ and $16 \mathrm{f}$ lies in the primordial deeds of God, 'from the times of old' $(\mu d q \mathrm{~m})$. Verses 12 and 15 are connected by references to the exodus.

In the verses $13 \mathrm{f}$ and $16 \mathrm{f}$ we find two other elaborate structures. Verses $13 \mathrm{f}(\mathrm{B})$ mentions the monsters of chaos against which Elohim fights and which probably have to be seen as God's enemies: The sea $(\mu y)$, the sea dragons Tannin and Leviathan and the $\mu y y x \mid \mu[\mid$, which are difficult to translate. The expression probably means 'people of the desert', which refers e.g. to hyenas, and not 'sharks of the sea', following an old conjecture'. There is a concentric element in the mentioning of the 'crushing' ( $\mathrm{b} b / \mathrm{A} \times \mathrm{r}$ ) of the 'heads' (war pl cs) of Tannin and Leviathan in the two hemistichoi in the center $(13 \mathrm{~b}, 14 \mathrm{a})$. There is, however, also an element of a parallel structure of the verses, which is formed by $h t a$ as the first word in verses 13a and 14a (Human 1993a:152).

There is no doubt about the concentric structure with regard to vv 16f. These two verses allude several times to the creation story of Genesis 1 . The two hemistichs in the centre begin with ht a. They speak about the divine order relating to the dimension of space. The stars and the sun mirror the totality of the heavenly sphere, as do 'all' the boundaries of the land for the earthly ${ }^{10}$. Elohim established, as outlined by Metzger and Hartenstein, the totality of the spacial order in creating heaven and earth with their specific borders ${ }^{11}$. The first and the last of the four hemistichs deal with the cyclical order of the time: the cycles of the day and the year. Therefore, the world order in its totality of space and time is described here as a work of God.

9 For discussion on the expression, cf Zenger (2000:358).

10 The 'boundaries of the earth' more reluctanty (likely?) refer to the boundaries between land and sea rather than to national borders.

11 Hartenstein $(1997: 242)$ with reference to the table given by Metzger (1983:43), which serves to illustrate the 'Sinnstruktur'of the verses. 
Embedded in these two artful structures is verse 15 with the allusion to the exodus. It is nothing that happened beyond 'ordinary' space and time, like the events described in verses $13 \mathrm{f}$ and $16 \mathrm{f}$, although it is given in a language that resembles the mythical one of the framing verses. One can conclude that the exodus has been viewed as a not completely non-mythical event in the time the psalm was written. Or, the other way around: speaking in mythical language does not at all diminish the truth of a biblical statement. We will come back to this later.

It is not only the very poetic structure and the mentioning of events in mythical time that are remarkable in part II of the psalm. What is not mentioned is also noteworthy, namely the theology of the name of God and the lament of Israel/Zion. We almost exclusively meet past tense in this part ${ }^{12}$, and the verses are not framed by the mentioning of Elohim's enemies. This communicates the message of this part: Elohim is the one who brings forth salvation for the land or earth ( $A r a$ ), as he has ever fought his enemies successfully. Elohim is no longer also a victim of Israel's enemies as in verse 10, but rules over them.

In this way, Elohim is pictured as the creator of space and time. $\mathrm{He}$ is the only one who offers escape in the situation which has been described in part I: The destruction that the enemies have brought to Israel/Zion in part I is total and complete. Hope can only come from someone who does not rule over the dimension of space alone, but who also has time in his hands. The mythical, eternal time $(\mu \mathrm{dgm})$ provides ground for the hope Israel puts in Elohim and his role as the king of land and people.

\subsubsection{Part III: verse 18-23}

The third part of the psalm opens with the imperative form $r k z$, 'remember'. $r k z$ has been used before in $v 2$ and is repeated in verse 22 , so that it also forms an overall frame for the psalm. Part III is framed mainly by mentioning the enemies of YHWH or Elohim and Israel in verses $18 \mathrm{a}, 18 \mathrm{~b}, 23 \mathrm{a}$ and $23 \mathrm{~b}$. This is the same framing technique and device as we found in part I. There is also a concentric structure in this part, which is found in 1 a + jussive in verse $19 \mathrm{a}$ and 23a (Human 1993b:208).

12 There is one exception in the imperfect Whit $t$ in verse $14 \mathrm{~b}$. This can be interpreted, however, as past tense (Hartenstein 1997:240, with note 67). 
For the first and only time in the psalm, YHWH and not Elohim is approached in verse 18. 'YHWH' is addressed in the verses up to 21 , as in verse 22 the divine is again called 'Elohim'. The verses 18-21 contain a number of motifs which are only found here and not elsewhere in the psalm. The Israelite people speak of themselves as a $r / t$, a species of fowl, probably the 'black francolin' ${ }^{13}$. The Israelites' enemies are described as 'wild beasts' (v. 19). The metaphors probably point to the defencelessness of the people. Whereas it is not easy to relate these motifs specifically to YHWH, this is different with three other traditions, namely the 'poor', the 'oppressed' or the 'miserable' (û yyn , Id or Iyba a) that are only mentioned in this passage (vv. 19b, 21a and 21b). This relates to the 'piety of the poor', which is frequently found in the psalms, where YHWH is often addressed as saviour ${ }^{14}$. $t$ yr $b$ (v. 20a) refers to another theological tradition, the covenant between Israel and YHWH, as well as is the praising of YHWH's name, which is only once mentioned in a positive way (v. 21b).

Not only in the second, but also in the third part of the psalm a new group of enemies arises. In part II, these have been the chaotic monsters in verses 13f. Now we find the 'fools' $(\mu y \mid b n)$ in verses $18 b$ and $22 \mathrm{~b}$. These are no longer the enemies from outside of the country which we came to know in part I, or the non-human monsters in part II. The psalm now refers to enemies that cannot be all that clearly distinguished from 'the people', except by their foolishness, which means their anti-social intellectual or ethical behaviour. In Israelite wisdom tradition, the $\mu y l b n$ are one group

$13 r / t$ is often translated as 'turtle dove'. Staubli (2001:48), however, points out that $\mathrm{r} / \mathrm{t}$ probably refers to the "black francolin": "Es gibt Gründe, die dafür sprechen, das hebräische Wort tor nicht wie in den Übersetzungen üblich mit 'Turteltaube/Esondern mit 'Wildhuhn/Ezu übersetzen. Das Wort ist auch im Akkadischen belegt (tarru) und bezeichnet dort eindeutig ein Wildhuhn, wahrscheinlich das häufige Halsbandfrankolin (Francolinus francolinus), das im Zweistromland als Haustier gehalten wurde. Diese Bedeutung ist auch für das tr anzunehmen, das in einer ugaritischen Opferanweisung vorkommt". The $r / t$ or black francolin in the Old Testament is mostly referred to as a sacrificial animal, whereas the ordinary dove ( $h / y)$ is also mentioned in the context of lament and mourning because of the sound of its voice (Is 38:14; 59:11; Ezk 7:16; Nah 2:8); cf Botterweck (1982:591f).

14 For the post-exilic theological tradition of Israel as the poor, cf Kraus (1979:188-193). 
which stands against the wise men and women. Fighting unwise behaviour or standing up for wisdom is also a royal task ${ }^{15}$. If one relates this to the image of David as the king of Israel, we find two encounters with non-wise people. Another group of enemies is mentioned in the last verse. Not only the $\mu y r r x$, who are already known from verse 4 and as $\mu y r v$ from verse 10, are named, but also 'those who stand up against you', the $\mu \mathrm{ymq}$. Now it is only Elohim at whom they aim and whom they try to harm, no more are the people seen as the victim.

The third part with its new groups of enemies centres around the strongest word the Hebrew Bible uses for violence, namely $s V^{\prime \prime}$ (v. 20b). In all corners of the land, severe forms of violent crimes are committed. This again demands Elohim to act.

What is new in the third part of the psalm is also the image of Elohim as judge or as fighting for justice. Two imperative forms $(\mu$ V and byr in v. 22a) ask Elohim to rise up and take action to establish justice. This task is also part of the royal role in Israel, but this theme is more elaborated in the following Psalm 75.

Other motifs than in parts I and II have been brought up in part III. Another group of enemies appears with the $\mu y l b n$, and the 'poor' Israelites are again asking YHWH and Elohim to take action, this time in the role of the divine judge. The very last word of the psalm, 'continually' (dymt), again refers to the most important dimension of the psalm and urges Elohim for the last time to act as king of his people and as their saviour.

\section{THE QUESTION OF MYTHICAL TRUTH}

To sum up the main results: In Psalm 74, the enemies of Israel/Zion and of Elohim/YHWH function as important figures in structuring the psalm. In parts I and III, the reference to the ever growing group of enemies is a framing element. Combined with expressions of totality in part I, the psalm evokes the impression already in the beginning that there is no escape from the enemies' destructive

15 This is said by Schmid (1968:24-46) and summarised by Adam (2001:13): There are "fünf verschiedene Bereiche, die dem König konstant zugeordnet werden: Der König ist für den Krieg gegen die Feinde zuständig, für die Wahrung des Rechts im Land und (in unterschiedlicher Weise) für den Kult; ferner verbindet die Überlieferung Weisheit und die Fruchtbarkeit des Landes mit ihm". 
action. Even the second mentioning of Elohim in verse 10 is 'surrounded' by the enemies, so that the sphere of space is completely dominated by the enemies. This is underlined by $A \mathrm{r}$ a as the word for 'land' or 'earth' (v. 7b, 8b), which is situated inside the literary space framed by the enemies (vv. 3b-10b).

As a counter-image, especially in part II of the psalm, the dimension of time is varied to create a sphere where hope can evolve. In verses 13-17, there are many references to what can be called mythical language or mythical traditions: Elohim fighting the dragons, Elohim fighting the waters to make Israel's escape from Egypt possible, and Elohim establishing the world order in time and space. These references to the mythical sphere are built on wellknown ancient Near Eastern traditions, which are also present in ancient Israel, as shown by many Old Testament texts ${ }^{16}$. The mentioning of the 'Chaoskampf' and of creation does not only refer to the primordial times, as Podella has shown (1993:309). Although some prominent ancient Near Eastern texts, e.g. the Babylonian Enuma elish might lead into this direction, fighting the dragons is a divine task that has to be performed all the time, and not only in connection with primordial creation. It is an everlasting duty of the divine to care for world order. The Chaoskampf is the mythical means to speak about this. The myth refers to some kind of platform or pool which contains images known in all of the ancient Near East. These images lie beyond what we today, in post-enlightenment times and after the overcoming of non-rationalist traditions, call historical belief or historical thought. In the ancient Near East and the Old Testament as participating in this cultural sphere, there was no such distinction of 'historical' and 'non-historical' events or traditions. Myths were an important part of the cultural heritage which claimed the same dignity as 'historical' events. In Psalm 74, the exodus can be described in very similar language than that in which the mythical references are set. We detect almost no distinction between these two spheres $^{17}$.

Why is it important for the psalm to refer to mythical traditions? The reason is to be sought in the destruction of almost

16 Cf. e.g. Gn 1f, Ps 82 or Ps 104.

17 Or, as Podella (1989:262) puts it: "Der Gegensatz von Mythos und Geschichte ist funktional aufgehoben". 
everything that resulted from Israel's being chosen by YHWH and their having been given the land. Even the temple in Jerusalem, the everlasting dwelling place of $\mathrm{YHWH}$, no longer existed as a place of worship. In these very desperate times, when every visible sign of God's power and his history with his people was ruined, the authors of Psalm 74 created new hope in referring to the only tradition which could not be inflicted by the violence of the enemies, namely the mythical traditions. The only visible tradition which still gave hope was creation with its everlasting order: day and night, and the borders between heaven and earth and between earth and the waters. These were the only remaining deeds of YHWH; and they could be observed by ordinary people. The psalm takes these cosmic rhythms and cosmic borders as elements of the world order and connects them to the exodus and the tradition of the Chaoskampf. Under the headline of Elohim as king of his people, the visible cosmic order is seen as a proof for the truth of the other two traditions, even if their consequences are no longer visible. The fighting side of God is seen as one side of God as creator. This argument functions as a means to call Elohim to action, and at the same time as a source of hope for Israel.

Another consequence of the hope gained by the switch to mythical traditions is that not only the dimension of time, but also that of space can be reconquered by Elohim: Ar a is no longer in the hand of the enemies like in part I (vv. $7 \mathrm{~b}, 8 \mathrm{~b}$ ), but in part II it is territory which is completely under the rule of Elohim (vv. 12b, 17a).

\section{CONCLUSIONS}

Mythical traditions - or the reference to a mythical repertoire of motifs - in Psalm 74 are not just a literary play on words or a somehow anachronistic allusion. It is an essential strategy in very desperate times to gain hope when there no longer seems to be any reason for hope. Even the exodus can be alluded to in mythical language ${ }^{18}$, and this is not done to downplay its significance.

What the authors of Psalm 74 invented in this very desperate situation, with the whole country in ruins and the temple wrecked, cannot be overestimated. They created hope in a hopeless situation by referring to a dimension beyond the visible sphere. The deeds of

18 Another example for this is Isaiah 51:9f, which points back to Isaiah 30:7, where Rahab is explicitly identified as Egypt. 
YHWH/Elohim in the mythical traditions cannot be reached by the enemies; this kind of God-established order cannot be destroyed by their violence.

This should remind one to speak respectfully about mythical traditions in the Bible. In the biblical view, God's truth and God's revelation cannot be fully experienced and described only by referring to the dimension of historical or provable occurrences ${ }^{19}$. There are also dimensions in the divine world which lie beyond these visible dimensions ${ }^{20}$. We should be careful not to loose these biblical traditions, in particular, when we live in a violent world, where many people can only gain hope by relying on a power which acts from or beyond the human or visible sphere.

\section{Consulted literature}

Adam, K-P 2001. Der königliche Held: Die Entsprechung von kämpfendem Gott und kämpfendem König in Psalm 18. Neukirchen-Vluyn: Neukirchener (WMANT 91).

Botterweck, J 1983. s v hnwy jônah. ThWAT III: 586-594.

Donner, H 1973. Argumente zur Datierung des 74. Psalms, in: Schreiner, J (ed), Wort, Lied und Gottesspruch: Beiträge zu Psalmen und Propheten: Festschrift für Joseph Ziegler, 41-50. Würzburg: Echter/Katholisches Bibelwerk.

Emmendörffer, M 1998. Der ferne Gott: Eine Untersuchung der alttestamentlichen Volksklagelieder vor dem Hintergrund der mesopotamischen Literatur. Tübingen: Mohr (FAT 21).

Hartenstein, F 1997. Die Unzugänglichkeit Gottes im Heiligtum: Jesaja 6 und der Wohnort JHWHs in der Jerusalemer Kulttradition. Neukirchen-Vluyn: Neukirchener (WMANT 75).

19 Zenger (1999:234) also refers to this, saying about mythical texts, "Solchen Texten gegenüber käme das hermeneutische Programm der Entmythologisierung einer Banalisierung oder einer Destruktion ihrer religiösen Kraft gleich".

20 Janowski (2001:22f) relates a similar question to his reflections on the biblical Weltbild in contrast to the present one: "Je virtueller die physische Welt wird, um so weniger Grund gibt es auch, nach ihrem symbolischen Gehalt und ihrer religiösen oder metaphysischen Bedeutung zu fragen. Dann ist auch die Frage nach einem ,Sinn des Lebens' müßig. Diese Frage wach zu halten - auch wenn wir sie anders beantworten als unsere Vorfahren -, ist vielleicht das Wichtigste, was uns die Beschäftigung mit dem Weltbild der Antike lehren kann". 
Human, D J 1993a. Die begrip "Berit" in 'n aantal klaagpsalms: 'n perspektief. Unpublished BD dissertation, University of Pretoria.

-, 1993b. Die struktuur en tradisiesamestelling van Psalm 74, Skrif en Kerk 14, 203-221.

Hunziker-Rodewald, R 2001. Hirt und Herde: Ein Beitrag zum alttestamentlichen Gottesverständnis. Stuttgart: Kohlhammer (BWANT 155).

Janoswki, B 2001. Das biblische Weltbild: Eine methodologische Skizze, in: id. \& Ego, Beate (eds), Das biblische Weltbild und seine altorientalischen Kontexte, 3-26. Tübingen: Mohr (FAT 32).

Koch, Klaus 1991. Qädäm: Heilsgeschichte als mythische Urzeit im Alten (und Neuen) Testament, in: Janowski, B \& Krause, M (eds). Klaus Koch: Spuren des hebräischen Denkens. Beiträge zur alttestamentlichen Theologie. Gesammelte Aufsätze Bd. 1, 248-280. Neukirchen-Vluyn: Neukirchener. [first published 1988].

Kraus, H-J 1979. Theologie der Psalmen. Neukirchen-Vluyn: Neukirchener (BK.AT XV/3).

Lelièvre, A 1976. YHWH et la mer dans le Psaumes, RHPhR 56, 253-275.

Metzger, M 1983. Eigentumsdeklaration und Schöpfungsaussage, in: Geyer, H$\mathrm{G}$ et al (eds), 'Wenn nicht jetzt, wann dann?': Aufsätze für Hans-Joachim Kraus zum 65. Geburtstag, 37-51. Neukirchen-Vluyn: Neukirchener.

Müller, H-P 1993. Entmythologisierung und Altes Testament, NZSTh 35, 1-27.

Oswalt, J N 1977. The Myth of the Dragon and Old Testament Faith, EvQ 49, 163-172.

Ploeg, J P van der 1974. Ps 74 and its Structure, in: Van Voss, M S H G H et al (ed) 1974. Travels in the world of the Old Testament: Studies presented to Prof. M A Beek on the occasion of his 65th birthday, 204-210. Assen: Van Gorcum.

Podella, T 1989. Sôm-Fasten: Kollektive Trauer um den verborgenen Gott im Alten Testament. Kevelaer/Neukirchen-Vluyn: Butzon \& Bercker/ Neukirchener (AOAT 224).

-, 1993. Der Chaoskampfmythos im Alten Testament: Eine Problemanzeige, in: Dietrich, M \& Loretz, O (Hg), Mesopotamica - Ugaritica - Biblica: Festschrift für Kurt Bergerhof zur Vollendung seines 70. Lebensjahres am 7. Mai 1992. Neukirchen-Vluyn: Neukirchener, 283-329 (AOAT 232).

Schmid, H H 1968. Gerechtigkeit als Weltordnung: Hintergrund und Geschichte des alttestamentlichen Gerechtigkeitsbegriffs. Tübingen: Mohr (BHTh 40).

Schmidt, W H 1996. Alttestamentlicher Glaube ( $8^{\text {th }}$ ed). Neukirchen-Vluyn: Neukirchener.

Staubli, T 2001. Tiere als Teil menschlicher Nahrung in der Bibel und im alten Orient, in: Keel, O \& id (Hg). ,Im Schatten Deiner Flügel': Tiere in der Bibel und im Alten Orient, 46-48. Fribourg: Universitäts-Verlag. 
Spieckermann, H 1989. Heilsgegenwart: Eine Theologie der Psalmen. Göttingen: Vandenhoeck (FRLANT 148).

Van der Ploeg, J P 1974. Ps 74 and its Structure, in: Van Voss, M S H G H et al (ed) 1974. Travels in the world of the Old Testament: Studies presented to Prof. M.A. Beek on the occasion of his 65th birthday, 204-210. Assen: Van Gorcum.

Weber, B 2000. Zur Datierung der Asaph-Psalmen 74 und 79, Bib. 81, 521532.

-, 2001. Der Asaph-Psalter: eine Skizze, in: Huwyler, B et al (eds), Prophetie und Psalmen: Festschrift für Klaus Seybold zum 65. Geburtstag, 117-141. Münster: Ugarit-Verlag (AOAT 280).

-, 2003. Werkbuch Psalmen II: Die Psalmen 73 bis 150. Stuttgart: Kohlhammer.

Weinfeld, M 1972. Deuteronomy and the Deuteronomistic School. Oxford: Clarendon.

Zenger, E 1999. Das Mythische in den Psalmen 84 und 85, in: Lange, A et al (eds). Mythos im Alten Testament und seiner Umwelt: Festschrift für HansPeter Müller zum 65. Geburtstag, 233-251. Berlin: de Gruyter (BZAW 278).

-, 2000. Psalm 74, in Hossfeld, F-L \& Zenger, E Psalmen 51-100, 355-372. Freiburg: Herder (HThKAT). 